\title{
LOCAL LEGAL RELATIONS IN THE CONTEXT OF ADMINISTRATIVE DECENTRALIZATION. PROSPECTS AND CHALLENGES
}

\author{
D. G. Alexandru, M. Olteanu (Popescu)
}

\author{
Dana Georgeta Alexandru \\ Faculty of Humanities and Social Sciences, Department of International Relations, Political \\ Sciences and Security Studies \\ "Lucian Blaga" University of Sibiu, Sibiu, Romania \\ *Correspondence: Dana Georgeta Alexandru, "Lucian Blaga" University of Sibiu, \\ 34 Calea Dumbrăvii St., Sibiu, Romania \\ E-mail: dana.alexandru.g@gmail.com

\section{Mihaela Olteanu ${ }^{1}$ (Popescu)} \\ Faculty of Public Administration \\ National School of Political Studies and Public Administration, Bucharest, Romania \\ *Correspondence: Mihaela Olteanu, NSPSPA, 6 Povernei St., District 1, Bucharest, Romania \\ E-mail: mihaelaolteanu@ymail.com
}

\section{Abstract}

Local legal relations have evolved steadily over the past twenty years, so now we are witnessing a redefinition of their concept, with the purpose of overcoming the traditional local autonomy in recognition of certain international legal capacity of local communities to participate in forms of decentralized cooperation.

The goal of our research is to identify new actors in the international relations, local communities, which under EU law and the Council of Europe acquire certain powers that would allow them, at least theoretically, employment among secondary actors on the stage of international law.

The study presents an examination of the documents governing international or local cooperation with the ultimate aim to highlight the consequences of these forms of cooperation, which they produce in the context of administrative decentralization.

Keywords: local cooperation, international relations, local community.

\section{Introduction}

The development of the role of local collectivity in the society and the requirements imposed by modernization has multiplied relations between communities both domestically and internationally. The legislative framework which puts such rights came quite late, as operational forms of intercommunity co-operation have developed since the 1960's in the European administrative space, and in the Romanian legislation, regulations are more recent, the years 2000.

Relations between local authorities are marked by a close co-operation, characterized by the initiative to show a more attractive image, especially from the perspective of investors. Co-operation between local authorities has become a necessity for strengthening local

\footnotetext{
${ }^{1}$ Beneficiary of the project "Doctoral scholarships for the development of the knowledge-based society" cofunded by the European Union, through the European Social Fund, Sectorial Operational Program Human Resources Development 2007-2013.
} 
structures by joint exercise of powers in order to promote development projects that serve local interests.

Relationships that are established between local collectivities go beyond border limits, so international co-operation has become a reality carefully analyzed in theory.

The European Charter of Local Self-Government ${ }^{2}$ is a document that states some principles likely to govern the interaction between local and central authorities. The objective of this document is to compensate for the lack of common European rules likely to appreciate and protect the rights of local authorities, which are the closest to the citizens.

The principle of local autonomy, enshrined in the European Charter of Local SelfGovernment, forms the local authorities and their ability to organize themselves in cooperative structures. Therefore, co-operation materializes territorial and legal autonomy. However, autonomy can know serious limitations, depending on the legislation of the states.

The Charter merely regulates the sphere of interactions between central authorities and local community by establishing and sharing responsibilities and indication mechanisms to facilitate these relations.

Designation of responsibility to local collectivities consists in autonomy, legality, general competence clause, subsidiary and delegation of powers. The second category of principles could be regarded as tools that ensure the normal conduct of relations established in different spheres of activity, namely co-operation, information, financial independence and supervision. While the first category of principles is defining the status of the community and the skills domain, the second one governs relations between communities.

Local Autonomy acquires new acceptations, extended to understand what meaning it was given before. Overcoming traditional local autonomy represents the recognition of certain international legal capacity of local communities to participate in forms of decentralized cooperation.

In the European administrative space, we notice at least three forms of co-operation between regions: cross-border, transnational and interregional co-operation. The first form concerns regional development of adjacent local collectivities (located just across a border state), the second form concerns co-operation between groups of European local authorities for integrated and harmonious development of the territory of the European Union and the third form includes co-operation of EU with third countries.

In classical international law it is recognized that only states can be primary subjects that act in international relations, conclude treaties and bear the consequences of noncompliance. In the last 20 years significant changes have occurred on the stage of international relations, in the sense that the presence of certain actors is felt-actors that may not fall into the category of primary subjects, but acquire certain powers that would allow them, at least theoretically, employment among secondary actors on the stage of international ${ }_{\text {law }}$. To be even more rigorous, we note that this phenomenon is particularly at European level in the range of the European Union and the Council of Europe, two regional organizations with regional vocation.

\footnotetext{
${ }^{2}$ Adopted in Strasbourg on 15 October 1985 and entered into force on 1 September 1988. Romania signed the Charter on October 4, 1994 and a ratified by Law no. 199 of 17 November 1997, published in the "Official Gazette of Romania”, Part I, no. 331 of November 26, 1977, except art. 7, paragraph 2 of this European instrument.

${ }^{3}$ They have the quality of subjects - of international law states, international organizations and nations or nations fighting for independence. For details see Stelian Scăunaş, International Public Law, C.H. Beck Publishing House, Bucharest, 2007, p. 104.
} 
In 1980, the European countries signed the European Outline Convention on CrossBorder Co-operation between Territorial Communities or Authorities ${ }^{4}$, adopted at Madrid on 21 May 1980. This convention has greatly facilitated cooperation between regions.

Each Contracting Party undertakes to facilitate and promote cross-border co-operation between territorial communities or authorities of other States Parties to the Convention in accordance with the constitutional provisions of each State.

The Additional Protocol to the Convention - contains in the provisions of Article 1, paragraph 2, the following provision: A cross-border co-operation agreement commits the sole responsibility of territorial communities or authorities which have concluded it. Therefore, this regulation brings cross-border co-operation to a higher level, providing in Article 3 that cross-border co-operation agreements concluded by territorial communities or authorities can create a cross-border body with legal personality or not.

A second Protocol to the European Outline Convention on Cross-Border Cooperation between Territorial Communities or Authorities ${ }^{5}$, states in its preamble that to fulfill their functions efficiently, territorial communities or authorities collaborate not only with neighboring communities in other states, but also foreign non-contiguous communities that have a community of interest (inter-territorial cooperation). For the purposes of this Protocol, inter-territorial co-operation means any consultation aimed at establishing relations between territorial communities or authorities of two or more Contracting Parties other than border cooperation reports of neighboring communities, including agreements with territorial communities or authorities in other states. Article 2, paragraph 2 of Protocol 2 of the Convention provides that an inter-territorial co-operation agreement commits the sole responsibility of territorial communities or authorities which have concluded it.

The situation remains somehow uncertain in terms of the legal commitment and the consequences of decisions these communities of work take. The Standing Conference of Local and Regional Authorities in Europe of the Council of Europe, in the name of transboundary communities, adopted in 1991 the Resolution 227 (1991) "on the foreign relations of territorial communities" which requests the Committee of Ministers to develop an Additional Protocol to strengthen the influence of European Outline Convention on CrossBorder Co-operation between Territorial Communities or Authorities which recognize:

- The power of local collectivities to maintain cross-border relations;

- The legal person in internal law of cross-border co-operation bodies;

- The legal value of national acts performed by these bodies".

In the specialty literature, the relation between such authorities or public bodies is also called low level relation, transnational or trans-border relation. The existence of intrastate agreements raises various issues related to their recognition by international law, as well as their impact on the unity of the state on the international stage given that the state is the only entity able to engage across borders. There are therefore two issues worth mentioning.

Therefore, we note that in order to preserve the coherence of the states international relations in trans-boundary relations, it is important for the State concerned to channel and focus the action of local collectivities in order to avoid any conflict between decentralized action taken to local and international commitments of the State.

Regarding the legal nature of interstate agreements, the doctrine stated that they are not Treaties, proposed qualifications being those of: political agreements, agreements of international law, national agreements or agreements sui generis.

\footnotetext{
${ }^{4}$ Government Ordinance no. 120/1998 for ratification by Romania of the European Outline Convention on CrossBorder Co-operation between Territorial Communities or Authorities adopted at Madrid on 21 May 1980, published in Official Gazette of Romania, Part I, no. 329 of 31 August 1998, approved with amendments by Law no. 78/1999.

${ }^{5}$ Concluded on 05 May 1998, in Strasbourg.
} 
States began to conclude, as we noted above, framework treaties which detail the conditions under which local communities can act with the intent to co-operate. Through the conditions imposed, states try to reconcile interests in order to ensure stronger co-operation between local entities and coherent external action to preserve the state. States wanted thereby to preserve the national law of such agreements.

Most of these treaties provide that any co-operation bodies that constitute - shall apply national law of one of the parties to the treaty framework. The state remains an indispensable player for the efficiency of cross-border territorial communities or authorities.

Most of these framework treaties, aim to facilitate and promote cross-border cooperation, while the local communities that have the right to be part to such agreements are rigorously specified, depending on each state's internal constitutional architecture.

Local communities' competence, to conclude such co-operation agreements is consistent with the principle of parallelism-skills so that agreements can be signed only in areas where entities have the same kind of powers under their intern law. Some materials are of course excluded from the co-operation. These are the fields that involve the exercise of sovereignty.

The European Outline Convention on Cross-Border Co-operation between Territorial Communities or Authorities presents a series of models and outlines agreements, statutes and contracts in terms of cross-border co-operation of territorial communities or authorities. Thus, we distinguish two main categories:

- Models of intergovernmental agreements ${ }^{6}$ concerning cross-border co-operation at regional and local levels;

- Outline agreements, contracts and statutes ${ }^{7}$, which can serve as a basis for crossborder co-operation between authorities and local authorities.

Covered by national and state laws, schemes are likely to immediate use, or subordinated to the adoption of an interstate agreement, which regulates their use. The system of these agreements, intended for local communities, corresponds to the models of interstate agreements. The Government Emergency Ordinance (GEO) no. 120/1998 for ratification by Romania of the European Outline Convention on Cross-Border Co-operation between Territorial Communities or Authorities represents the legal frame of cross-border cooperation activities conducted by local authorities and communities in our country.

The principal provisions of Law no. 215/2001 are completed with the Government Ordinance no. 120/1998 for the ratification of the European Outline Convention on CrossBorder Co-operation between Territorial Communities or Authorities and the provisions of Law no. 315/2004 on regional development ${ }^{8}$. According these law, co-operation represents a component of the regional development policy which aims are to ensure balanced economic growth, social development and sustainable development of border regions.

Regarding the procedure for concluding agreements by local intrastate, the Romanian legislator has limited the exercise of these rights by amending the legislative act ${ }^{9}$ which was

\footnotetext{
${ }^{6}$ Under intergovernmental agreements we distinguish the following models: the inter-state agreement on promoting cross-border cooperation model; the interstate agreement on cross-border regional consultation model; the interstate agreement on local border pooling model.

${ }^{7}$ Regarding schemes of agreements, contracts and statutes between local authorities we distinguish: the outline agreement on the creation of a consultation between local authorities; the scheme to coordinate the management of local public affairs cross-border agreement, the scheme for creating cross-border private law associations; the scheme of supply contract or a supply of services between local (non-private) and the scheme supply contract or a supply of services between local border's (public) agreement scheme creating inter-border cooperation bodies.

${ }^{8}$ Published in the Official Gazette of Romania, Part I, no. 577 from the $29^{\text {th }}$ of June 2004, as corrected by Correction no. 315/2004, modified and completed by Government Emergency Ordinance no. 111/2004.

${ }^{9}$ Law no. 129/2003, published in the Official Gazette of Romania, Part I, no. 260 from April the 15th 2003, art. 2 from Government Emergency Ordinance no. 120/1998 have been modified.
} 
originally ratified in the Framework Convention. So, the legislator has introduced in Art. 2 of Government Emergency Ordinance (GEO) no. 120/1998 the following provisions: „Crossborder co-operation is subordinated to the conclusion of intergovernmental agreements and the application of the provisions regarding cross-border co-operation is limited to the territory surrounding counties. Local communities, authorities or bodies exercising regional functions, under Romanian law are represented by county councils and local councils".

Provisions of art. 15 and following of Law 215/2001 on local public administration, regulates the procedure of exercising the right to co-operation and association of local communities with other communities in the country or abroad as follows:

- Local initiative to co-operate and associate with other communities abroad and to join an international association shall be notified to the Ministry of Foreign Affairs and the Ministry Administration and Internal Affairs.

- The projects of co-operation agreements that territorial administrative units intend to conclude with local authorities in other countries will be submitted for approval to the Ministry of Foreign Affairs, through mayors, or Presidents of County Councils, prior to submission for approval by Local Councils or Councils County, as appropriate.

- These notices must be issued within 30 days of receiving the request. Otherwise it will be considered that there are no objections and the project can be submitted for approval to the Local Council or County in case.

- The decisions regarding the participation in programs of county, regional, zonal development or border co-operation is adopted by a majority of local councilors in office. Responsibility for co-operation agreements concluded by local communities belongs exclusively with them.

- Through the border co-operation agreements, it can be created within the Romanian territory certain bodies endowed with legal personality. These bodies have, in the present law, administrative-territorial powers. Local authorities that have concluded agreements of border co-operation have the right to participate in other Member bodies created by those agreements, within their competence.

The procedure regarding the assent has been criticized. In the literature was estimated that this regulation is anachronistic ${ }^{10}$ for the following reasons: establishing this task to the local community it prejudices the principle of local autonomy, so that the right to judge on whether initiating external co-operation belongs no longer to the local community, but to the state. In these circumstances the state can paralyzes the association, co-operation or accession to procedure by issuing a negative opinion regarding initiating external co-operation. In a different opinion it is supported that the control exercised by the Ministry over the activity of local or county councils, by issuing this opinion represents a classic exercised trusteeship administrative control.

As far as we are concerned, we believe that the requirement for obtaining the notice is likely to infringe local communities to express freely. The possibility to prejudice the unitary and indivisible character of the state through association or co-operation agreements does not exist; because unlawful ${ }^{11}$ decisions that adopt these agreements may be censured by the administrative court, in the exercise of judicial review by the Prefect.

In conclusion, we consider that the provisions on international co-operation are intended to reinforce and to develop neighborly relations between territorial communities or authorities, which depend on two or more contracting parties, as well as on agreements and understandings necessary for this purpose.

\footnotetext{
${ }^{10}$ A. Trăilescu, Administrative Law, C.H. Beck Publishing House, Bucharest, 2010, p. 40.

${ }^{11}$ According to art. Article 16.3 of Law no. 215/2001 "The opinions provided in par. (2) must be issued within 30 days of receipt of the request. Otherwise it will be considered that there are no objections and the project can be submitted for approval to the local council or county concerned".
} 


\section{Conclusions}

1. Regarding local legal relations, we noticed that the local autonomy acquires new meanings, extended to the understanding that it was given before. Overcoming traditional local autonomy represents the recognition of certain international legal capacities of local communities to participate in forms of decentralized co-operation.

2. The nature of this phenomenon calls for reflection; can it be an irreversible process or will it disappear due to the lack of funds for various projects? Scenarios ${ }^{12}$ foresee the emergence of certain transnational representatives, transnational budgets and, why not, a representation in the European institutions of forms for cross-border co-operation.

\section{Bibliography}

J.-B. Auby, La decentralization, le droit et l'État, $2^{\mathrm{e}}$ edition, L.G.D.J., Paris, 2010;

A. Trăilescu, Administrative Law, C.H. Beck Publishing House, Bucharest, 2010;

J. Schwarze (coord), L'état actuel et les perspectives du droit administratif européen, Bruylant Publishing House, Brusseles, 2010; 2009;

J. B. Auby, J. F. Auby, R. Noguellou, Droit des collectivités locales, PUF, Paris,

E. Bălan, Instituții administrative, C.H. Beck Publishing House, Bucharest, 2008;

R. M. Beşteliu, International Public Law, vol. I, C.H. Beck Publishing House, Bucharest, 2008;

J.-B. Auby., J. Dutheil de la Rochère, Droit administratif européen, Bruylant Publishing House, Brussels, 2007;

J.-B. Auby, La decentralisation et le droit, L.G.D.J., Paris, 2006;

D. A. Tofan, European Administrative Institutions, C.H. Beck Publishing House, Bucharest, 2006;

F. Niculae, Models of regionalization in the context of European integration, Ph.D. thesis, University of Bucharest, Faculty of Law, Doctoral School, Bucharest, 2000.

\footnotetext{
${ }^{12}$ N. Fabian, Models of regionalization in the context of European integration, University of Bucharest, Faculty of Law, Doctoral School, Bucharest, 2009, Abstract, PhD Thesis, p. 70.
} 